\title{
EFFECTS OF DIETARY FATS ON HUMAN ERYTHROCYTE FATTY ACID PATTERNS *
}

\author{
By JOHN W. FARQUHAR $\dagger$ AND EDWARD H. AHRENS, JR.
}

(From the Rockefeller Institute, New York, N. Y.)

(Submitted for publication August 28, 1962; accepted January 17, 1963)

The extent to which the fatty acids of dietary fats imprint themselves on the fatty acid compositions of various human tissues has been studied in this laboratory over the last five years. Previous reports have described effects in human chyle (1), serum (2), breast milk $(3,4)$, adipose tissue (5), and atheromata (6).

The present study focuses attention on the mature human erythrocyte (RBC). For a number of reasons this tissue has special interest. Its membrane is in part lipid; rates of transfer of many plasma constituents across this membrane may be affected by chemical changes in the membrane lipid; it readily exchanges its free cholesterol with that of the serum lipoproteins; and, in contrast to most other tissues, it has virtually no capacity to synthesize and incorporate fatty acids into phospholipids. Hopefully, what is learned about the structure and function of erythrocyte membranes may be applied directly to the outer or plasma membrane of other cells. A previous report (7) has described in detail the lipid composition of normal human erythrocytes, including the plasmalogen content and composition of their aldehydes, and the fatty acid compositions of three of the four major phospholipid species (ethanolamine-, serine-, and choline-phosphoglycerides).

The extensive changes in erythrocyte fatty acids caused by feeding corn oil for as little as 10 days were described in 1959 by Leibetseder and Ahrens (8). The same year Horwitt, Harvey, and Century showed similar effects in patients fed corn oil for four years (9). Both studies showed that although linoleic acid in erythrocyte fatty acids rose to about 1.5 times the original level, the absolute increase was only $5 \%$ of total fatty acids,

* This work was supported in part by U. S. Public Health Service grant H-2539 from the National Heart Institute, Bethesda, Md.

† Address correspondence to: Dr. John W. Farquhar, Department of Medicine, Stanford University School of Medicine, Palo Alto, Calif. an increase that is small when compared to dietary effects on other tissues (1-6). But, interpretation of any changes in fatty acid composition of erythrocytes, however small, must take account of three special features of red cell composition (7). 1) Erythrocyte lipids are made up mainly of free cholesterol and phospholipids (Figure 1, left). The percentage of total erythrocyte fatty acids in defined lipids other than phospholipids is less than $3 \%$; these are derived from small amounts of glycerides, cholesterol esters, and free fatty acids. (Lipids more polar than the phospholipids,

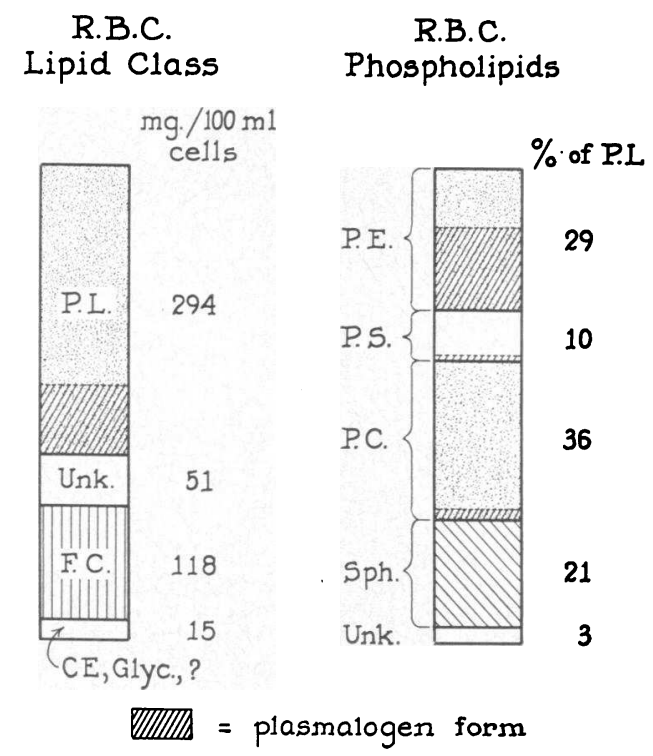

Fig. 1. LiPID CLASSES OF ERYThROCYTES OF 14 HEALTHy medical Students (9 male, 5 female). Data represent the average of values of each of the 14 individuals. Left: Five lipid classes in $\mathrm{mg}$ per $100 \mathrm{ml}$ packed erythrocytes (chloroform: methanol extracts). P.L. = phospholipids ; Unk = unknown lipid; F.C. $=$ free cholesterol ; C.E. $=$ cholesterol esters ; Glyc. = glycerides. Total weight $=480 \mathrm{mg}$ per $100 \mathrm{ml}$ washed cells. An additional $80 \mathrm{mg}$ of lipids more polar than phospholipids and not present in the final extract was not characterized. Right: Four phospholipid classes. P.E. = ethanolamine phosphoglycerides; P.S. = serine phosphoglycerides; P.C. = choline phosphoglycerides; Sph. = sphingomyelin. 
but still undefined, comprise $9 \%$ of total erythrocyte lipids.) 2) The classes of phospholipids in red cells are similar to those in other tissues, but their proportions differ, especially from those in the plasma. Lecithins make up $35 \%$ of total phosphatides in erythrocytes and $75 \%$ in plasma, whereas ethanolamine phosphoglycerides form $30 \%$ of total phosphatides in erythrocytes and only $5 \%$ in plasma, and serine phosphoglycerides constitute $10 \%$ of erythrocyte phosphatides but are virtually absent from plasma. Plasmalogens comprise only 3 to $5 \%$ of plasma phosphatides, but $20 \%$ of total phosphatides in erythrocytes (mostly in ethanolamine phosphatide, Figure 1, right). 3) About $50 \%$ of the erythrocyte phospholipid fatty acids are unsaturated, whereas 65 to $75 \%$ of fatty acids are unsaturated in the neutral lipids of such tissues as plasma (2), adipose tissue (5), and aorta (6). To recapitulate, the esterified lipids of erythrocytes differ from those of many other tissues by consisting almost exclusively of phospholipids, a class of lipids in which saturated and unsaturated fatty acids are about equally distributed (7). Moreover, in erythrocytes, the lecithins (whose unsaturation consists largely of fatty acids common in dietary fats, 18:1 and 18:2) are overbalanced, in weight proportions, by phospholipid classes containing $\mathrm{C}_{20-22}$ polyunsaturated acids uncommon in dietary triglycerides. Thus, the possibility of imprinting a common unsaturated dietary fat on the fatty acid composition of erythrocytes cannot be denied, but the magnitude of the alteration is necessarily lower than in the case of other tissues.

This report describes the effects on the fatty acid patterns of total phospholipids and of the individual phosphatide classes of erythrocytes when ad libitum and fat-free diets are fed, as well as diets containing one or another well-defined and chemically distinguishable fat. Data are presented on alterations in aldehyde chains ${ }^{1}$ of the plasmalogen forms of these phospholipids, and on comparison of erythrocyte phosphatide with adipose tissue triglyceride fatty acids in different dietary states. More detailed studies on struc-

\footnotetext{
1 The aldehydogenic chains of plasmalogen phosphatides are termed aldehydes, since fatty aldehydes are released from these molecules on acid hydrolysis. In the native state they are linked to acylated phosphoglycerides as $\alpha, \beta$-unsaturated ethers.
}

tural variability in the separate phospholipid classes of both fatty acids and aldehydes will be described elsewhere (10).

The present findings raise certain interesting questions about mechanisms of lipid exchange and sites of synthesis of red cell lipids and indicate a potential use of erythrocyte fatty acid patterns in studies of fat malabsorption. In addition, the data may have some immediate practical value for investigators planning prospective epidemiologic studies of coronary heart disease, where objective indexes of adherence to one or another dietary program are needed.

\section{METHODS}

Red cells were obtained from 24 normal subjects and from 22 patients of whom 14 were studied in the course of months-long feeding studies on a metabolic ward (11). In the hospital the use of orally fed liquid formulas as sole source of nutriments permitted one dietary fat to be fed at a time (12). Vitamin and mineral supplements provided optimal amounts of these essentials, and protein comprised $15 \%$ of total calories. Patients were maintained in continuous energy balance, neither gaining nor losing body weight. Synthetic fats of known composition were generously furnished by Dr. Fred L. Mattson, Procter and Gamble Co., Cincinnati, Ohio.

Red cells were concentrated by centrifugation immediately after collection of blood in tubes containing disodium EDTA, and the cells were washed free of plasma by centrifuging them twice through normal saline. Erythrocyte phospholipids were prepared as described elsewhere (7), essentially by extraction in chloroformmethanol and isolation by chromatography on columns of silicic acid (13). Separations into ethanolamine-, serine-, and choline-phosphoglycerides and sphingomyelins were accomplished on columns of silicic acid at $4^{\circ}$ to $8^{\circ} \mathrm{C}$ (7). Adipose tissue was obtained by needle aspiration (5). Phospholipid fatty acids of erythrocytes and adipose triglyceride fatty acids were converted to methyl esters by transmethylation (14), and methyl esters were analyzed by gas-liquid chromatography (GLC) (15). Erythrocyte phospholipid plasmalogen aldehydes were converted to volatile derivatives and identified by techniques previously published (16). Accuracy of GLC quantification was assured by linearity testing with U. S. Public Health Service Metabolism Study Section fatty acid standards A-F. Fatty acids were identified by their retention times on polar and nonpolar solvents (15) and are designated by a shorthand system in which the chain length and number of double bonds are specified, for example, linoleic acid $=18: 2$. Since auto-oxidation of phospholipids, particularly of cephalin fractions, occurs rapidly $(17,18)$, certain precautions were taken at every stage. Wherever possible, work was carried out at $4^{\circ} \mathrm{C}$ or below, under nitrogen, and in presence of $0.01 \%$ hydro- 
TABLE I

Fatty acid composition (mole per cent) of erythrocyte phospholipid classes during ad libitum feeding*

\begin{tabular}{ccccc}
\hline \hline Fatty acids & $\begin{array}{c}\text { Ethanolamine } \\
\text { phosphoglycerides }\end{array}$ & $\begin{array}{c}\text { Serine } \\
\text { phosphoglycerides }\end{array}$ & $\begin{array}{c}\text { Choline } \\
\text { phosphoglycerides }\end{array}$ & Sphingomyelin \\
\hline $16: 0$ & 19 & 7 & 33 & 24 \\
$18: 0$ & 8 & 42 & 21 & 5 \\
$18: 1$ & 25 & 16 & 3 & 5 \\
$18: 2$ & 7 & 20 & 5 & 1 \\
$20: 4$ & 22 & 31 & 16 & 348
\end{tabular}

* Analysis of pooled blood of three normal male adults. A more detailed list of fatty acids of the three phosphoglyceride classes is presented in reference 7 .

$\dagger$ Fatty acids not tabulated made up $<5 \%$ of total.

$\ddagger$ Including $20: 4$.

$\S$ In addition, $28 \%$ of total acids $=\mathrm{C}_{20-24}$ saturates.

quinone as antioxidant; materials were stored at $-20^{\circ} \mathrm{C}$ before analysis. Evidence of necessity for these precautions has been presented (7).

The validity of examining phospholipid fatty acids as if they were a homogeneous group may be questioned. Table I shows, in fact, that the fatty acid patterns of the four major phospholipid classes are very different. Nevertheless, we found no change in proportions of phospholipid classes during four different dietary fat regimens (see Results), and therefore in most tables and figures the phospholipid fatty acid data are presented as a single group.

\section{RESULTS}

\section{Ad libitum diets}

Fatty acids of erythrocyte phospholipids in patients consuming diets of their own choosing are shown in Table II. There is good agreement among individual and pooled normal data.

The total phospholipids of erythrocytes are remarkable for their high levels of palmitic $(16: 0)$ and of $\mathrm{C}_{20}$ and $\mathrm{C}_{22}$ unsaturated acids, particularly arachidonic $(20: 4)$. Linoleic acid $(18: 2)$ averages 10 to $12 \%$, a concentration similar to that in normal human adipose tissue (5) and in the fat of the average American diet (19). The oleic acid $(18: 1)$ contents of these three materials are very different, however, as are the levels of $\mathrm{C}_{20-22}$ acids. The ratios of $18: 1$ and $18: 2$ in plasma and erythrocyte phospholipids in patients eating ad libitum are strikingly dissimilar.

\section{Effects on erythrocyte lipid classes of various dietary states}

Table III shows that variations in kind and amount of dietary fat produced only small changes in amounts of the major erythrocyte lipids and in distribution of phospholipid classes. Although more data are needed, particularly in separate phospholipid classes, it is our belief that the varia-

TABLE II

Fatty acid compositions (mole per cent) of various lipids during ad libitum feeding

\begin{tabular}{|c|c|c|c|c|c|c|c|c|}
\hline \multirow[b]{3}{*}{ Fatty acids* } & \multicolumn{5}{|c|}{ R BC phospholipid fatty acids } & \multirow{3}{*}{$\begin{array}{c}\text { Plasma } \\
\text { phospho- } \\
\text { lipids } \\
\text { Normal } \\
\text { male } \\
35 \text { yrs }\end{array}$} & \multirow[b]{3}{*}{$\begin{array}{c}\text { Normal } \\
\text { adipose } \\
\text { tissue† }\end{array}$} & \multirow[b]{3}{*}{$\begin{array}{c}\text { USA } \\
\text { dietary } \\
\text { fat } \ddagger\end{array}$} \\
\hline & \multicolumn{2}{|c|}{ Normal pools } & \multirow[b]{2}{*}{$\begin{array}{c}\text { Normal } \\
\text { male } \\
36 \text { yrs }\end{array}$} & \multirow[b]{2}{*}{$\begin{array}{c}\text { Normal } \\
\text { male } \\
38 \text { yrs }\end{array}$} & \multirow{2}{*}{$\begin{array}{c}\text { Hyper- } \\
\text { choles- } \\
\text { teremic } \\
\text { female } \\
32 \text { yrs }\end{array}$} & & & \\
\hline & $\begin{array}{l}3 \text { Males } \\
29-33 \text { yrs }\end{array}$ & $\begin{array}{l}9 \text { Males } \\
5 \text { Females } \\
22-28 \text { yrs }\end{array}$ & & & & & & \\
\hline $16: 0$ & 29 & 31 & 33 & 30 & 30 & 28 & 20 & $41 \S$ \\
\hline $18: 0$ & 16 & 15 & 17 & 13 & 13 & 16 & 4 & \\
\hline $18: 1$ & 17 & 21 & 19 & 20 & 20 & 11 & 46 & 43 \\
\hline $18: 2$ & 12 & 11 & 10 & 12 & 12 & 19 & 11 & 10 \\
\hline $20: 4$ & 9 & 10 & 10 & 9 & 9 & 11 & trace & trace \\
\hline $\mathrm{C}_{20-22}$ unsats. & 19 & 21 & 19 & 21 & 22 & 22 & 1 & trace \\
\hline
\end{tabular}

* Fatty acids not tabulated made up $<5 \%$ of total, except in case of adipose tissue which is rich in 16:1 (5).

+ See reference 5 .

$\ddagger$ See reference 19

Figure cited $=$ total saturated fatty acids.

|| Including $20: 4$. 


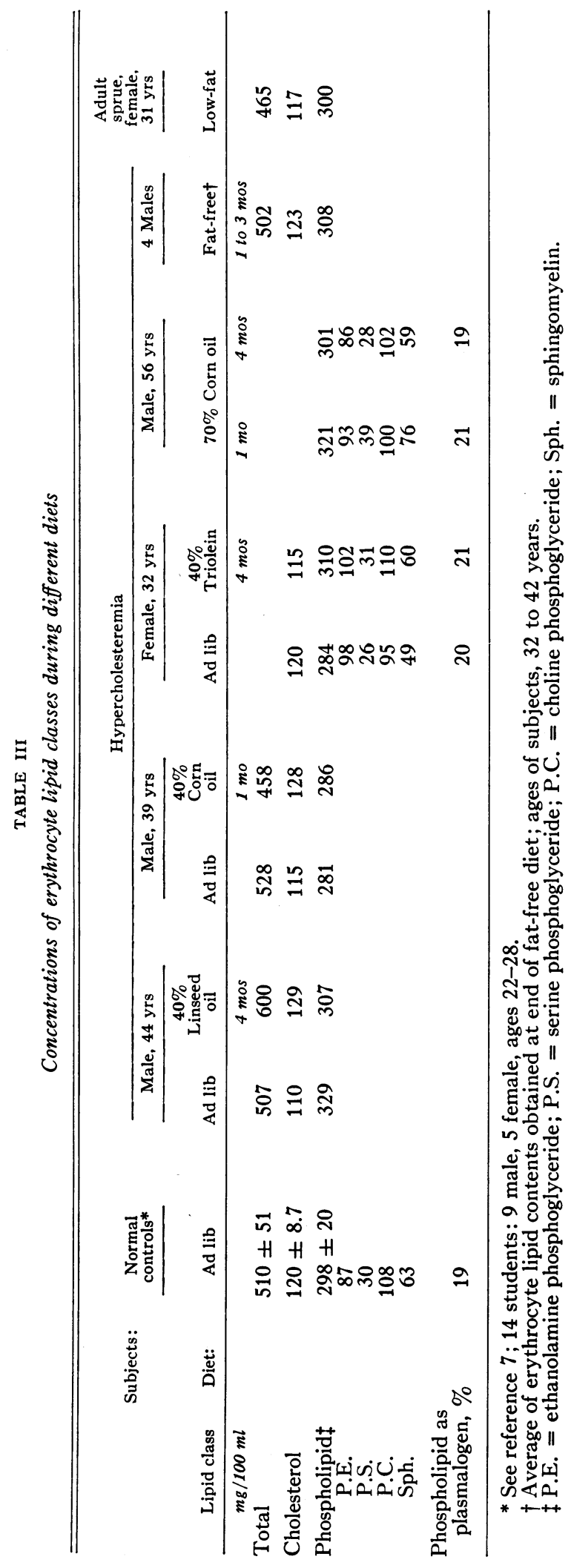

tions are not due to dietary influences but more likely result from summation of errors of analytical methods (7). For example, since lecithin and sphingomyelin are incompletely separated (7), the somewhat greater variability of sphingomyelin than of other lipid classes (Table III) may thus be explained. This source of error can now be eliminated by use of recent refinements in chromatographic technique (20).

\section{Fat-free diet}

Analyses were made of the fatty acids of erythrocyte phospholipids in four hypercholesteremic males on fat-free, carbohydrate-rich formulas for periods of more than 4 to 11 weeks. Although a high-carbohydrate regimen promotes lipogenesis (21), mammalian species do not synthesize 18:2 and $20: 4$ (22). Thus, large amounts of $16: 1$, $18: 0$, and $18: 1$ are formed when dietary carbohydrate comprises the major source of calories. Table IV shows a decrease in $18: 2$ on the fat-free diet to about half the concentration on ad libitum diets. There were balancing increases in 18:0 and 18:1. The $\mathrm{C}_{20-22}$ unsaturates and 16:0 remained unaffected, and no increase in $20: 3$ occurred despite reports of appearance of large amounts of this acid in erythrocytes of Rhesus monkeys fed fat-free diets for period of 8 months or more (23).

Table IV includes erythrocyte and adipose tissue fatty acid compositions of four individuals whose habitual diets were known to be considerably lower than normal in $18: 2$ content. Since the effect of short-term dietary changes on erythrocyte fatty acids and of long-term dietary changes on adipose (5) fatty acids has now been defined, it is of interest in the steatorrheas and other clinical disorders to correlate adipose and erythrocyte fatty acid compositions when the amount of $18: 2$ habitually absorbed is difficult to assess. In each of the three patients with chronic steatorrhea, adipose tissue 18:2 (Table IV) was from 40 to $50 \%$ of normal, and all had 50 or less of the amount of $18: 2$ in their erythrocyte phospholipids than we have found in normal subjects on ad libitum diets (Table II). Thus, erythrocyte and adipose 18:2 levels of all three steatorrhea cases were comparably low. In a-beta-lipoproteinemia (absence of beta-lipoproteins), the 
TABLE IV

Fatty acids (mole per cent) of erythrocyte phosphatides and of adipose tissue during fat-free and low-fat diets

\begin{tabular}{|c|c|c|c|c|c|c|c|c|c|c|}
\hline \multirow{4}{*}{$\begin{array}{l}\text { Erythrocyte } \\
\text { fatty acids* }\end{array}$} & & & & & \multicolumn{4}{|c|}{ Habitual low-fat diets } & & \\
\hline & & & & & \multirow{3}{*}{$\begin{array}{l}\text { Glyco- } \\
\text { genosis } \\
\text { (Von } \\
\text { Gierke's } \\
\text { disease) } \\
\text { o' } 6 \text { yrs } \\
\text { (5 yrs) }\end{array}$} & \multicolumn{3}{|c|}{ Steatorrhea } & & \\
\hline & \multicolumn{4}{|c|}{$\begin{array}{c}\text { Short-term experimental } \\
\text { fat-free diets } \\
\text { Hypercholesteremic males }\end{array}$} & & \multirow{2}{*}{$\begin{array}{l}\text { Post- } \\
\text { pan- } \\
\text { crea- } \\
\text { titis } \\
\sigma^{7} \\
66 \mathrm{yrs} \\
(2 \mathrm{yrs})\end{array}$} & \multirow{2}{*}{$\begin{array}{l}\text { Non- } \\
\text { trop- } \\
\text { ical } \\
\text { sprue } \\
\sigma^{\pi} \\
31 \text { yrs } \\
(3 \text { yrs })\end{array}$} & \multirow{2}{*}{$\begin{array}{c}\text { A- } \beta- \\
\text { lipo- } \\
\text { protein- } \\
\text { emia } \\
\sigma^{7} \\
33 \text { yrs } \\
(30 \text { yrs })\end{array}$} & \multicolumn{2}{|c|}{$\begin{array}{c}\text { Normal } \\
\text { full-term } \\
\text { newborn } \\
\text { infants }\end{array}$} \\
\hline & $\begin{array}{c}32 \mathrm{yrs} \\
(6) \dagger\end{array}$ & $\begin{array}{c}34 \text { yrs } \\
(6)\end{array}$ & $\begin{array}{c}41 \mathrm{yrs} \\
(4)\end{array}$ & $\begin{array}{c}42 \mathrm{yrs} \\
\text { (11) }\end{array}$ & & & & & $\sigma^{7} \mathrm{~A}$ & $\overline{\sigma^{x} \mathrm{~B}}$ \\
\hline $\begin{array}{c}16: 0 \\
18: 0 \\
18: 1 \\
18: 2 \\
20: 4 \\
C_{20-22} \text { unsat. } \$\end{array}$ & $\begin{array}{r}32 \\
19 \\
24 \\
5 \\
7 \\
19\end{array}$ & $\begin{array}{r}33 \\
18 \\
20 \\
6 \\
10 \\
19\end{array}$ & $\begin{array}{r}31 \\
15 \\
22 \\
4 \\
10 \\
23\end{array}$ & $\begin{array}{r}28 \\
20 \\
22 \\
4 \\
7 \\
18\end{array}$ & $\begin{array}{r}30 \\
16 \\
19 \\
3 \\
12 \\
30\end{array}$ & $\begin{array}{r}31 \\
16 \\
21 \\
6 \\
13 \\
22\end{array}$ & $\begin{array}{r}28 \\
14 \\
23 \\
5 \\
10 \\
24\end{array}$ & $\begin{array}{r}29 \\
14 \\
20 \\
3 \\
11 \\
27\end{array}$ & $\begin{array}{r}33 \\
12 \\
13 \\
4 \\
17 \\
29\end{array}$ & $\begin{array}{r}32 \\
12 \\
13 \\
4 \\
18 \\
33\end{array}$ \\
\hline $\begin{array}{l}\text { Adipose tissue } \\
18: 2 \\
\mathrm{~N}=10-12 \% \|\end{array}$ & & $10 \|$ & & & $3 \|$ & 4 & 5 & 4 & & \\
\hline
\end{tabular}

* Fatty acids not tabulated made up $<5 \%$ of total.

$\dagger$ Numbers in parentheses indicate time in weeks of fat-free feedings or of years of low-fat diets.

$\neq$ Absence of beta-lipoproteins.

$\$$ Including $20: 4$.

Reference 5 .

I Reference 26 . Ten full-term infants.

altered distribution of phosphatides in erythrocytes $(24,25)$ may be an additional cause of low $18: 2$ contents in the abnormal erythrocytes which are typical of this disorder.

Data from one case of glycogen-storage disease (5) and from twelve full-term normal newborns are included in Table IV. In the glycogenosis patient, the habitual diet was purposely high in carbohydrate and low in fat. The 18:2 contents of adipose tissue of 10 infants (26) and erythrocytes of two infants were very low. Other evidence (5) indicates that fetal lipogenesis is brisk during the last few weeks of pregnancy, when placental transfer of maternal fatty acids is minimal. In erythrocytes of newborns, 18:1 also was lower than in normal adults; there were balancing increases in $\mathrm{C}_{20-22}$ unsaturates and very large amounts of $20: 4$.

\section{Corn oil diets}

Corn oil is a convenient dietary fat marker because of its high (55\%) content of $18: 2$. Shortand long-term effects on erythrocyte fatty acids were defined in patients fed corn oil as sole dietary fat.

Single dose. Corn oil, $110 \mathrm{~g}$, was fed in a single feeding after an overnight fast to a 42-yearold male with hypercholesteremia and hyperlipemia, who for many weeks had been maintained on a fat-free formula. The test meal contained protein, corn oil, and carbohydrate in a ratio of $15: 70: 15 \%$ of total calories. The subsequent feedings were fat-free. Figure 2 shows that the erythrocyte phospholipids accumulated very small amounts of dietary 18:2 in 1 day, although the phospholipids of the plasma low-density lipoproteins doubled their content of this acid over the course of the day.

Daily feedings, $40 \%$ corn oil calories. Table V

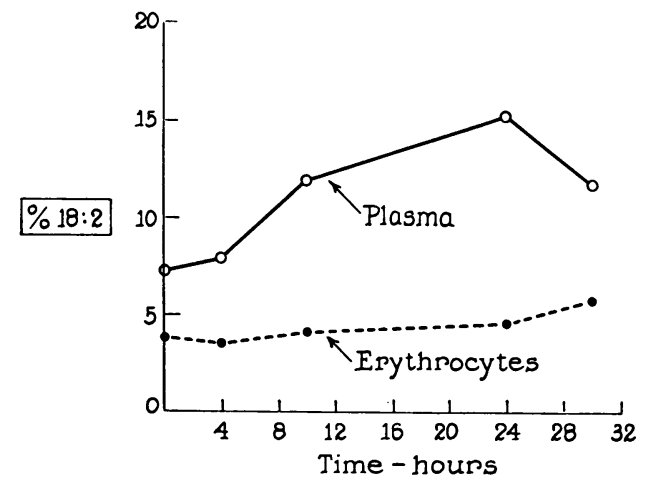

Fig. 2. EfFect of Single dose of CORN OIL ON PLASMA AND ERYTHROCYTE PHOSPhatides. $100 \mathrm{~g}$ corn oil fed at 9 a.m. to a 42-year-old male with hypercholesteremia and hyperlipemia, maintained for previous 6 weeks on fat-free formula. Plasma $=$ phosphatides of $\beta$-lipoproteins (density 1.006 to 1.063 ) isolated by ultracentrifugation. 
TABLE V

Fatty acid compositions (mole per cent) of erythrocyte phospholipids in six hypercholesteremic patients after six or more weeks on corn oil formulas

\begin{tabular}{|c|c|c|c|c|c|c|}
\hline \multirow[b]{2}{*}{ Fatty acids* } & \multicolumn{5}{|c|}{$40 \%$ of calories as corn oil } & \multirow{2}{*}{$\begin{array}{l}70 \% \text { Corn oil } \\
\text { Male }\end{array}$} \\
\hline & Male & Male & Male & Male & Female & \\
\hline & 39 yrs & $42 y r s$ & 50 yrs & 61 yrs & 37 yrs & $61 \mathrm{yrs}$ \\
\hline $16: 0$ & 28 & 31 & 30 & 30 & 28 & 28 \\
\hline $18: 0$ & 15 & 13 & 13 & 13 & 16 & 9 \\
\hline $18: 1$ & 18 & 15 & 15 & 15 & 17 & 15 \\
\hline $18: 2$ & 16 & 15 & 15 & 16 & 15 & 27 \\
\hline $20: 4$ & 9 & 10 & 11 & 9 & 10 & 10 \\
\hline $\mathrm{C}_{20-22}$ unsat. $\dagger$ & 20 & 23 & 27 & 18 & 21 & 18 \\
\hline
\end{tabular}

* Fatty acids not tabulated up $<5 \%$ of total.

$\dagger$ Including $20: 4$.

shows the effect of feeding a formula containing $40 \%$ of calories as corn oil for 6 or more weeks to 5 patients. In all, there were significant increases of 18:2 over contents found on ad libitum diets (Table II), but no changes in 20:4 or in $\mathrm{C}_{20-22}$ unsaturates. Transitions in fatty acid compositions were completed in 4 to 6 weeks, with no significant rise thereafter in 18:2 content for as long as 2 years. Despite major alterations in serum lipid concentrations on this regimen (11), it is remarkable that there were no significant changes in absolute concentrations of lipid classes in the erythrocytes (Table III).

Daily feedings, $70 \%$ corn oil calories. Table V lists data obtained in a male hypercholesteremic patient during 7 months on a formula containing

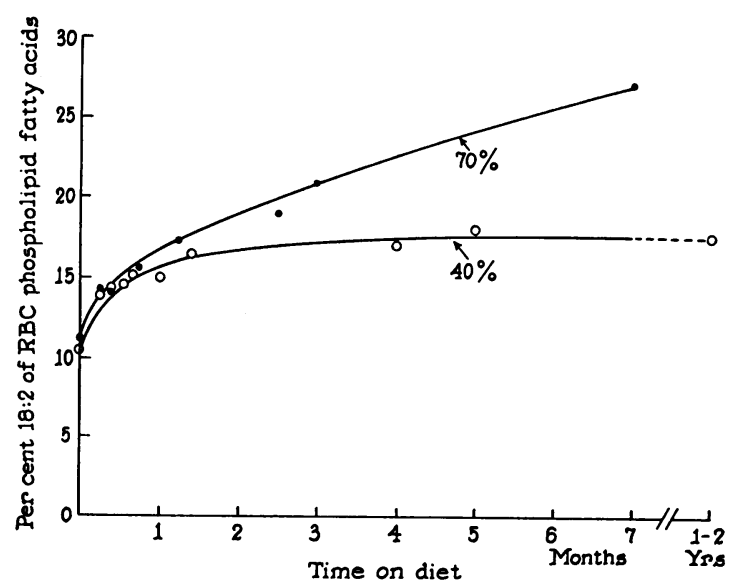

Fig. 3. EFFECTS of FORMUla diets CONTAining $70 \%$ AND $40 \%$ OF CALORIES AS CORN OIL ON ERYTHROCYTE $18: 2$ CONCENTRATION (AS MOLE PER CENT OF TOTAL PHOSPHOLIPID FATTY ACIDS). Upper line = hypercholesteremic male, age 61 . Lower line $=$ hypercholesteremic males, ages 32 to 61 .
$70 \%$ of calories as corn oil. The 18:2 level in erythrocyte phospholipids rose promptly from 11 to $17 \%$ in 4 weeks (Figure 3 ), the time at which equilibrium was obtained in patients fed $40 \%$ of fat calories. However, Figure 3 shows a further increase of 18:2 over the following 6 months, to reach the highest level we have seen in any patient $(27 \%)$. There were no significant effects on proportions of erythrocyte lipid classes, however (Table III).

Each phosphatide class participated in the 18:2 change (Figure 4, top). Bearing in mind the distribution of phospholipid classes in the erythrocytes (7), we found that the greatest absolute increase in 18:2 occurred in lecithin and the second greatest increase occurred in P.E. (ethanolamine phosphoglyceride). There was very little change in the remaining two major phospholipid classes, serine phosphoglyceride and sphingomyelin.

\section{Other well-defined fats}

Experiments have been carried out in six patients with four other fats fed at $40 \%$ of total calories-linseed oil, synthetic triolein, and two other synthetic triglycerides composed 1) solely of palmitic and linoleic acids $(50: 50)$ and 2) solely of palmitic and oleic acids $(50: 50)$. The results are in accord with those presented above: 1) transitions in fatty acid patterns took place over the first 4 weeks, then remained constant ; 2) oleic and linoleic acids replaced each other, leaving other acid concentrations relatively unchanged; and 3) fatty acid patterns changed with diet in all the phospholipid classes, parallel in time, but to 
different degree (Figure 4). Small increases of palmitic (apparently at the expense of stearic) acid were found in the erythrocyte lipids after feeding the two synthetic triglycerides rich in 16:0. However, when linseed oil (6.5\% linoleic and $50.5 \%$ linolenic) was fed for 12 months, the linolenic (18:3) content of the erythrocyte phospholipid fatty acids rose from 0.1 to only $1.6 \%$, while over the same period of time the content of $18: 3$ in adipose tissue rose from 0.2 to $17 \%$. Although this degree of change would be expected in adipose tissue in 12 months (5), the failure of 18:3 to appear as a constituent of the erythrocyte phospholipids is an intriguing observation which remains unexplained.

\section{Dictary 18: 2 vs. crythrocyte 18: 2}

A linear relationship was found between the 18: 2 content of the diet (expressed as percentage of total calories) and the 18:2 content of erythrocyte phospholipids. Figure 5 summarizes feeding tests in 14 patients, with fats of varying $18: 2$ concentrations fed at several caloric levels. These data were obtained after 6 weeks to 24 months on each feeding regimen. The erythrocyte $18: 2$ levels of nine groups of control subjects (24 subjects, total) consuming ad libitum diets are included. Their 18:2 intake was assumed to be $4.5 \%$ of total dietary calories (19).

Effect of $40 \%$ triolein and $70 \%$ corn oil diets on 18: 1 and 18: 2 aldehydes of erythrocyte ethanolamine plasmalogens

Fatty aldehyde compositions of erythrocyte ethanolamine plasmalogen were readily altered by dietary means, and their response to daily feedings of $40 \%$ triolein or $70 \%$ corn oil for $4 \frac{1}{2}$ to 7 months are depicted in Figure 4. Oleyl aldehyde

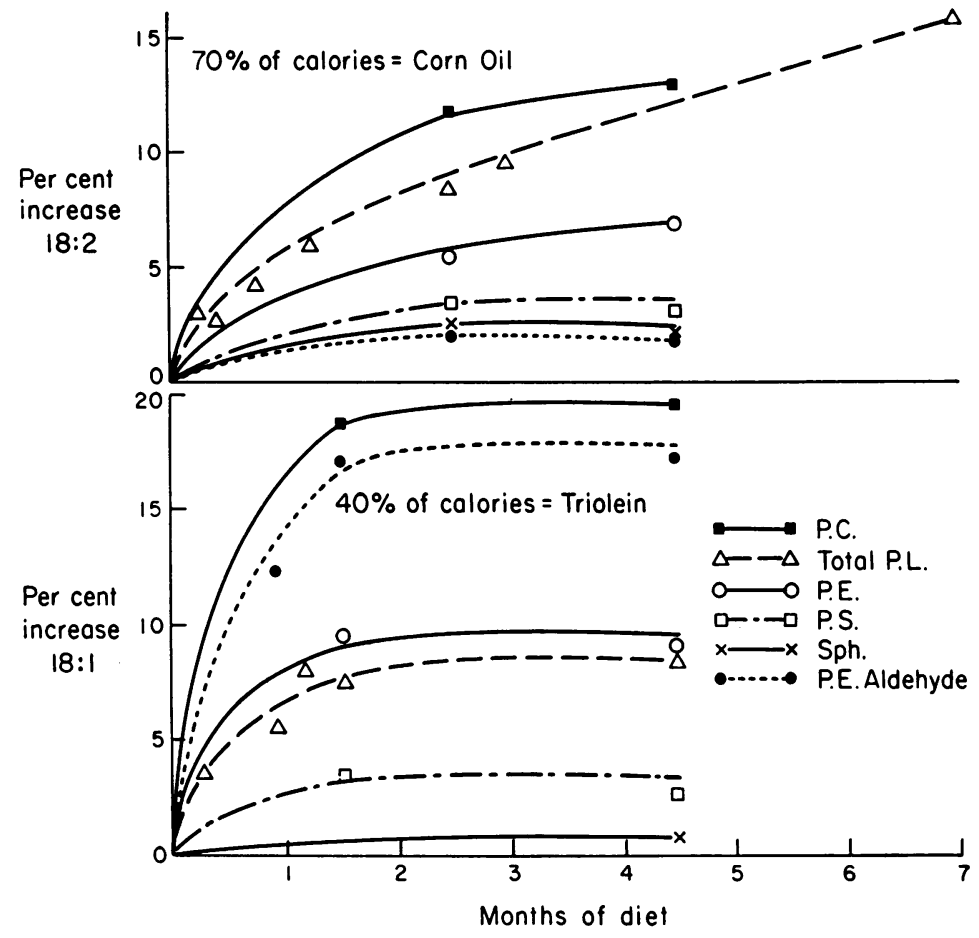

Fig. 4. EFfects on Separate erythrocyte Phospholipid Classes of FORMULA DIETS CONTAINING $70 \%$ OF CALORIES AS CORN OIL (TOP) OR $40 \%$ OF CALORIES AS TRIOLEIN (воTTOM). P.C. = choline phosphoglycerides; total P.L. = total phospholipids; P.E. = ethanolamine phosphoglycerides ; P.S. = serine phosphoglycerides $;$ Sph. $=$ sphingomyelin $;$ P.E. aldehyde $=$ ethanolamine plasmalogen aldehyde. All data plotted as mole per cent rise in $18: 1$ or $18: 2$ fatty acid, except P.E. aldehyde, which is plotted as mole per cent rise in $18: 1$ or $18: 2$ aldehyde. 


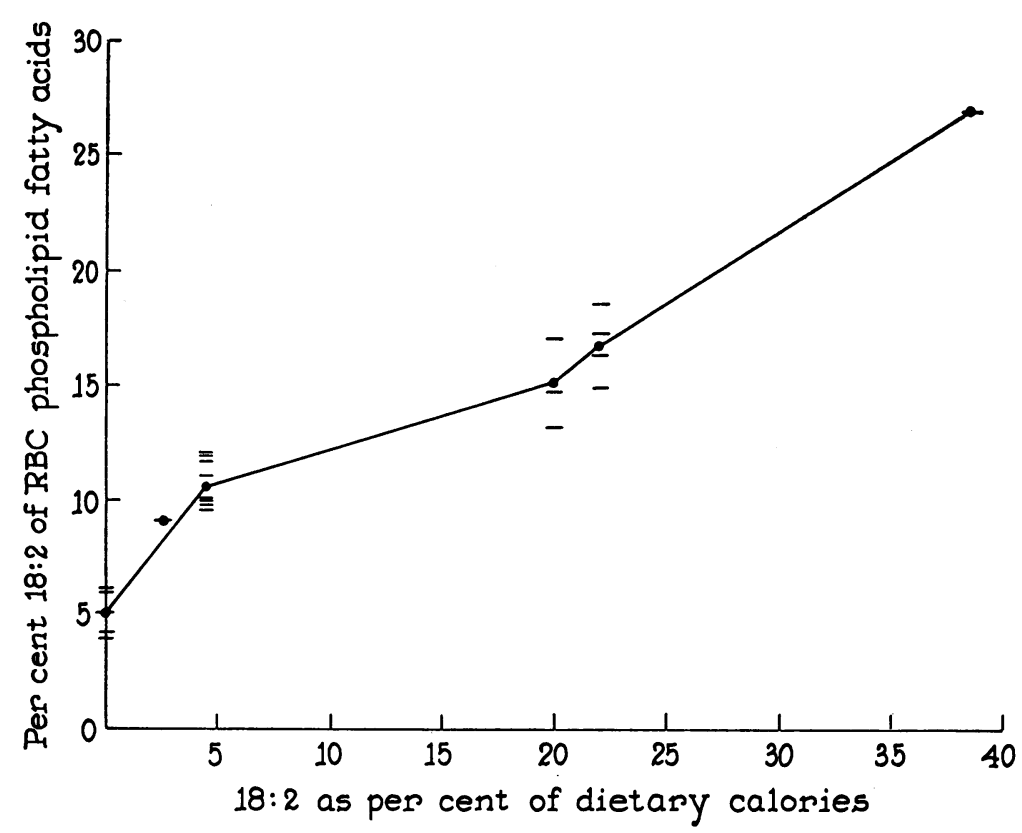

Fig. 5. Relationship of 18:2 of diet (AS PERCENtage of total CAlORIES) AND 18:2 OF ERYTHROCYTE PHOSPHOLIPIDS (AS MOLE PER CENT OF TOTAL FATTY ACIDS). Data obtained from nine groups of control subjects (24 individuals in total) on ad libitum diets (18:2, approximately $4.5 \%$ of calories) and from 14 patients after 6 weeks to 24 months on formulas varying in $18: 2$ content.

(18:1 aldehyde) underwent a striking increase by one month after ingestion of triolein and remained at a constant level after 6 weeks. The rate and degree of increase of ethanolamine plasmalogen (P.E.) oleyl aldehyde and choline phosphoglyceride (P.C.) 18:1 acid (Figure 4, bottom) were comparable (17 to $20 \%$ ). In contrast, however, after feeding $70 \%$ of calories as corn oil ( $43 \%$ calories as linoleic acid) to another patient, only a small increase, $2 \%$, in linoleyl aldehyde occurred (Figure 4, top). In neither of these experiments did the absolute amount of erythrocyte plasmalogen change significantly (Table III).

\section{DISCUSSION}

It is generally agreed that the mature human erythrocyte has virtually no capacity for sterol or phospholipid synthesis (27-29), although some ability for synthesis of neutral lipid from acetate, presumably triglyceride, has been reported (29-31). Also, evidence has been presented in this communication that the types and amounts of the major erythrocyte lipid classes are relatively unaffected by dietary changes (Table III). There- fore, a study of the rates of dietary-induced change in fatty acid composition of the erythrocyte phospholipids may indicate whether the incorporation of fatty acids into red cells occurs only when new cells are formed. When one or another marker fat is fed, the accumulation of new acids and the disappearance of acids previously ingested suggests an analogy to accretion and decay curves in isotope studies. To this end we have plotted the increase in 18:2 and decrease in 18:1 when corn oil is fed as sole dietary fat, and the decrease of 18:2 and increase in 18:1 when triolein is fed (Figure 6). New steady states were attained after 4 to 6 weeks on a given regimen, and the degree of change was \pm 5 to $10 \%$ of total fatty acids. (Clearly, the degree of variation in 18:1 and 18:2 can be magnified by relating their contents to each other or to that of an unchanging component like $16: 0$.) If a new fatty acid were incorporated into red cells only at the time of maturation in the marrow, a linear rise in concentration of that acid would be found in the mature cells over a 4-month period (the normal life span of erythrocytes), and conversely, a prolonged decay curve. The data 
in Figure 6 indicate, however, that incorporation of new acids takes place mainly by mechanism(s) other than incorporation during erythropoiesis in bone marrow.

Exchanges of fatty acids or of intact phospholipids must, therefore, occur between mature erythrocytes and one or more precursor pools. The in vitro and in vivo experiments of Hevesy (32) and of Hahn and Hevesy (32) with rabbit blood and of Reed (33) with human blood have demonstrated exchange of $\mathrm{P}^{32}$ between plasma and erythrocyte phosphatides, and Kunkel and Bearn (34) described in vitro exchange of $\mathrm{P}^{32}$-labeled phospholipids between high- and low-density lipoproteins. Although the rate of exchange for lecithin in vitro calculated by Reed $(10 \%$ per 24 hours) (33) would have caused a more rapid effect on erythrocyte lecithin than that shown in Figure 4, differences in experimental conditions make strict comparison meaningless. Clearly, further experiments with doubly labeled compounds will be required to elucidate the mechanisms of the exchanges postulated to occur be- tween plasma lipids and erythrocytes, and to determine whether intact phospholipids are exchanged or only their fatty acids. Sites of in vivo exchange other than with plasma must be sought, in view of the participation of serine phosphoglyceride in the fatty acid changes (Figure 4) and the reported absence of this lipid from cell-free plasma (33).

It is reasonable to suggest that phospholipid exchange may be analogous to that demonstrated by Hagerman and Gould (35) for free cholesterol, another major structural lipid of the erythrocyte. On the premise that erythrocyte lipids occupy fixed loci in the plasma membrane, their exchange may be determined by opportunities for contact with similar lipids in pools which are turning over more rapidly. Consistent with this concept are two factors: 1) the lack of dependency of cholesterol exchange on normal function of the principal energyyielding systems of the erythrocytes (36) and 2) the fixed, nonexchanging chemical structure of myelin (37), a reduplicated plasma membrane very similar in lipid composition to that of eryth-

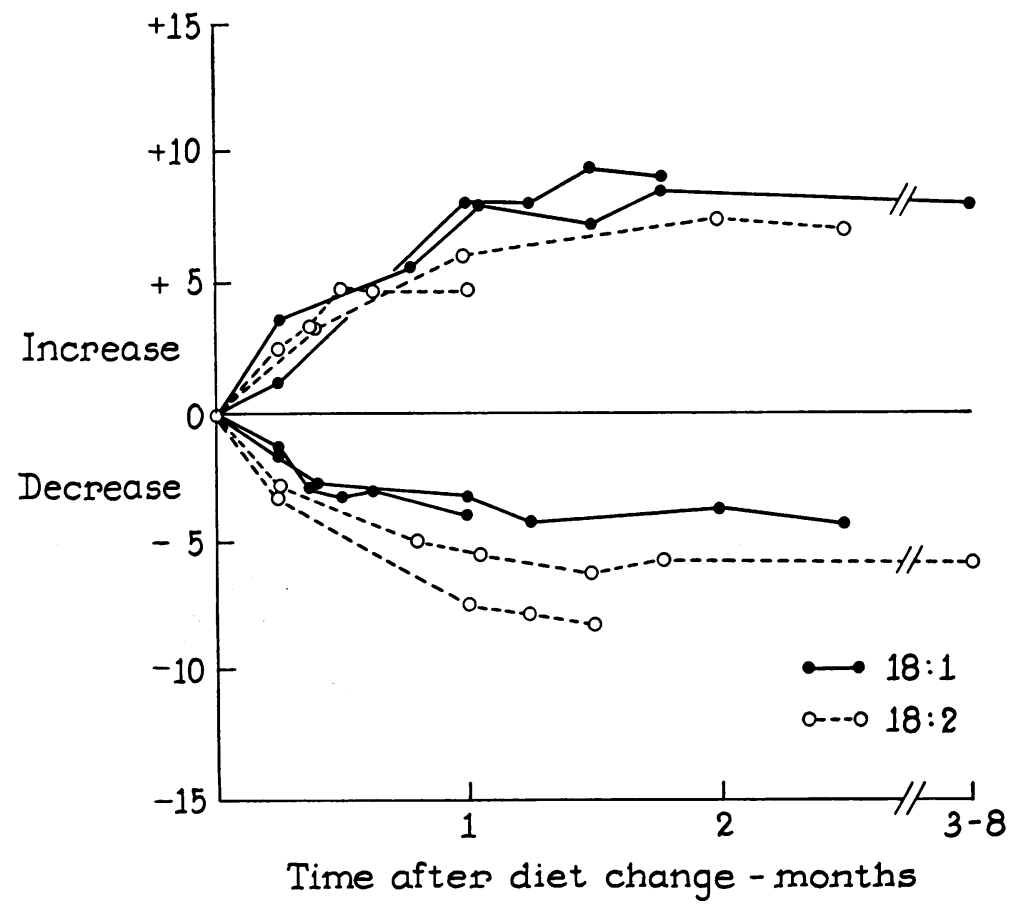

Fig. 6. Reciprocal changes in 18:1 and 18:2 Contents of erythroCYTE PHOSPHOLIPID FATTY ACIDS WITH DIETS RICH IN 18:1 (SYNTHETIC TRIOLEIN) OR IN 18:2 (CORN OIL). Diets fed at $40 \%$ of calories to four subjects for periods up to 8 months. Changes charted as increases or decreases in mole per cent of total erythrocyte phospholipid fatty acids. 
rocytes, yet anatomically isolated from contact with plasma or other rapidly metabolizing pools.

Figures 4, 5, and 6 demonstrate that the $18: 2$ level in erythrocyte phospholipids is a function of $18: 2$ content in the diet and that this effect occurs over a few weeks (not days, as in the case of plasma lipids, nor months, as in the case of adipose triglycerides). These findings suggest that measurements of erythrocyte fatty acid patterns may be useful as indexes of adherence to prescribed diets in large-scale, long-term feeding studies in man. To rely on fatty acid variations in plasma lipids may be misleading, since these variations occur so rapidly. Indeed, large changes could be achieved by artful adherence just before tests are carried out. Conversely, adipose tissue patterns change so slowly that they would indicate adherence or nonadherence only after many months, perhaps years (5). In our opinion, adherence to a diet high in linoleic acid over periods of a few months to a year may best be evaluated by measurements of erythrocyte fatty acid patterns, with particular attention to ratios of $18: 2$ to $16: 0$. We add the warning that studies of erythrocyte lipids must be carried out with meticulous care to avoid auto-oxidation and formation of artefacts $(7,17,18)$.

The interdependence of dietary and erythrocyte $18: 2$, coupled with the observed reductions in adipose tissue and erythrocyte $18: 2$ in patients whose dietary 18:2 intake has been low for years, suggests that erythrocyte response to known intake of dietary 18:2 may prove a useful means of assessing degrees of fat malabsorption in clinical disorders.

\section{SUMMARY}

1. Fatty acid patterns of human erythrocyte phospholipids and the effects of various defined diets on them are described. On ad libitum diets the linoleic acid $(18: 2)$ content is about $10 \%$ of total phospholipid fatty acids. It can fall to $5 \%$ or less when diets low in 18:2 are eaten, or can rise to as much as $27 \%$ on diets rich in linoleic acid. Reciprocal changes occur in oleic acid (18:1) contents.

2. Equilibrium between dietary fatty acids (fed at $40 \%$ of calories) and erythrocyte fatty acids and aldehydes occurs in 4 to 6 weeks. This finding indicates that exchanges occur between ma- ture erythrocytes and certain precursor pools, rather than solely by incorporation of dietary fatty acids into maturing erythrocytes in the marrow. It remains to be determined whether plasma is the principal precursor pool from which erythrocyte fatty acids are derived.

3. All four major phospholipid classes participate at equal rates in the changes which occur in total erythrocyte phosphatide. Aldehyde changes suggest that reduction of preformed fatty acids occurs in plasmalogen synthesis.

4. The rate at which fatty acid changes occur in red cells is slower than that for the plasma lipids, but more rapid than for adipose tissue. These features recommend measurements of erythrocyte phospholipid fatty acids in large-scale prospective feeding experiments in man as an index of adherence.

\section{REFERENCES}

1. Peterson, M. L. The transport of fat in man: a study of chylomicrons (dissertation). New York, The Rockefeller Institute, 1960.

2. Ahrens, E. H., Jr., J. Hirsch, M. L. Peterson, W. Insull, Jr., W. Stoffel, J. W. Farquhar, T. Miller, and H. J. Thomasson. The effect on human serum-lipids of a dietary fat, highly unsaturated, but poor in essential fatty acids. Lancet 1959, 1, 115.

3. Insull, W., Jr., and E. H. Ahrens, Jr. The fatty acids of human milk from mothers on diets taken ad libitum. Biochem. J.. 1959, 72, 27.

4. Insull, W., Jr., J. Hirsch, T. James, and E. H. Ahrens, Jr. The fatty acids of human milk. II. Alterations produced by manipulation of caloric balance and exchange of dietary fats. J. clin. Invest. 1959, 38, 443.

5. Hirsch, J., J. W. Farquhar, E. H. Ahrens, Jr., M. L. Peterson, and W. Stoffel. Studies of adipose tissue in man. A microtechnic for sampling and analysis. Amer. J. clin. Nutr. 1960, 8, 499.

6. Farquhar, J. W., R. L. Hirsch, and E. H. Ahrens, Jr. Evidence that atheroma fatty acids are in flux (abstract). J. clin. Invest. 1960, 39, 984.

7. Farquhar, J. W. Human erythrocyte phosphoglycerides. I. Quantification of plasmalogens, fatty acids and fatty aldehydes. Biochim. biophys. Acta (Amst.) 1962, 60, 80.

8. Leibetseder, F., and E. H. Ahrens, Jr. The fattyacid composition of red cells in paroxysmal nocturnal haemoglobinuria. Brit. J. Haemat. 1959, 5, 356.

9. Horwitt, M. K., C. C. Harvey, and B. Century. Effect of dietary fats on fatty acid composition of human erythrocytes and chick cerebella. Science 1959, 130, 917. 
10. Farquhar, J. W. In preparation.

11. Ahrens, E. H., Jr., W. Insull, Jr., R. Blomstrand, J. Hirsch, T. T. Tsaltas, and M. L. Peterson. The influence of dietary fats on serum-lipid levels in man. Lancet 1957, 1, 943.

12. Ahrens, E. H., Jr., V. P. Dole, and D. H. Blankenhorn. The use of orally fed liquid formulas in metabolic studies. Amer. J. clin. Nutr. 1954, 2, 336.

13. Hirsch, J., and E. H. Ahrens, Jr. The separation of complex lipide mixtures by the use of silicic acid chromatography. J. biol. Chem. 1958, 233, 311.

14. Stoffel, W., F. Chu, and E. H. Ahrens, Jr. Analysis of long-chain fatty acids by gas-liquid chromatography: micromethod for preparation of methyl esters. Analyt. Chem. 1959, 31, 307.

15. Farquhar, J. W., W. Insull, Jr., P. Rosen, W. Stoffel, and E. H. Ahrens, Jr. The analysis of fatty acid mixtures by gas-liquid chromatography: construction and operation of an ionization chamber instrument. Nutr. Rev. 1959, 17, suppl. 8.

16. Farquhar, J. W. Identification and gas-liquid chromatographic behavior of plasmalogen aldehydes and their acetal, alcohol, and acetylated alcohol derivatives. J. Lipid Res. 1962, 3, 21.

17. Lea, C. $\mathrm{H}$. Some observations on the preparation and properties of phosphatidylethanolamine in Biochemical Problems of Lipids, G. Popják and E. Le Breton, Eds. London, Butterworths, 1956, p. 81.

18. Rouser, G., J. O'Brien, and D. Heller. The separation of phosphatidyl ethanolamine and phosphatidyl serine by column chromatography. J. Amer. Oil chem. Soc. 1961, 38, 14.

19. U. S. Dept. of Agriculture. Household food consumption survey, 1955. Washington, D. C., 1957, Report 10.

20. Rouser, G., A. Bauman, G. Kritchevsky, D. Heller, and J. S. O'Brien. Quantitative chromatographic fractionation of complex lipid mixtures: brain lipids. J. Amer. Oil chem. Soc. 1961, 38, 544.

21. I.yon, I., M. S. Masri, and I. L. Chaikoff. Fasting and hepatic lipogenesis from $\mathrm{C}^{14}$-acetate. J. biol. Chem. 1952, 196, 25.

22. Elsbach, P. Composition and synthesis of lipids in resting and phagocytizing leukocytes. J. exp. Med. 1959, 110, 969.

23. Greenberg, L. D., and H. D. Moon. Alterations in the blood fatty acids in single and combined de- ficiencies of essential fatty acids and vitamin $B_{6}$ in monkeys. Arch. Biochem. 1961, 3, 405.

24. Ways, P., C. F. Reed, and D. J. Hanahan. Abnormalities of erythrocyte and plasma lipids in acanthocytosis (abstract). J. clin. Invest. 1961, 40, 1088.

25. Phillips, G. B. Quantitative chromatographic analysis of plasma and red blood cell lipids in patients with acanthocytosis. J. Lab. clin. Med. 1962, 357.

26. Hirsch, J., and J. Bagdade. Unpublished data.

27. Buchanan, A. A. Lipid synthesis by human leucocytes in vitro. Biochem. J. 1960, 75, 315.

28. Marks, P. A., A. Gellhorn, and C. Kidson. Lipid synthesis in human leukocytes, platelets, and erythrocytes. J. biol. Chem. 1960, 235, 2579.

29. Rowe, C. E., A. C. Allison, and J. E. Lovelock. Synthesis of lipids by different human blood cell types. Biochim. biophys. Acta (Amst.) 1960, 41, 310.

30. Mendelsohn, D. The metabolism of the human red blood cell. I. Interrelationships of carbohydrate and lipid metabolism in the human erythrocyte in vivo. A comparison between diabetic patients and normal subjects. S. Afr. J. med. Sci. 1961, 26, 15.

31. Mendelsohn, D. The metabolism of the human red blood cell. II. Interrelationships of carbohydrate and lipid metabolism in the human erythrocyte in ritro. A comparison between diabetic patients and normal subjects. S. Afr. J. med. Sci. 1961, 26, 24.

32. Hevesy, G. Radioactive Indicators. New York, Interscience, 1948, p. 456.

33. Reed, C. F. Studies of in vivo and in vitro exchange of erythrocyte and plasma phospholipids (abstract). J. clin. Invest. 1959, 38, 1032.

34. Kunkel, H. G., and A. G. Bearn. Phospholipid studies of different serum lipoproteins employing $\mathrm{P}^{32}$. Proc. Soc. exp. Biol. (N. Y.) 1954, 86, 887.

35. Hagerman, J. S., and R. G. Gould. The in vitro interchange of cholesterol between plasma and red cells. Proc. Soc. exp. Biol. (N. Y.) 1951, 78, 329.

36. Murphy, J. R. Erythrocyte metabolism. IV. Equilibration of cholesterol-4- $\mathrm{C}^{\mathbf{1 4}}$ between erythrocytes and variously treated sera. J. Lab. clin. Med. 1962, 60,571 .

37. Davison, A. N., and J. Dobbing. Phospholipid metabolism in nervous tissue. 2. Metabolic stability. Biochem. J. 1960, 75, 565. 